\section{Organochlorine insecticide poisoning in Golden Langurs Trachypithecus geei}

\section{D.C. Pathak}

Department of Pathology, College of Veterinary Science, Assam Agricultural University, Khanapara, Guwahati, Assam 781022, India

Email: dcp55@sify.com

The Golden Langur Trachypithecus geei, an old world monkey, is found on the Indian subcontinent mainly in the foothills of the Himalaya, along the Assam-Bhutan border inhabiting mainly areas with high trees. The species is classified as endangered (IUCN 2011). The herbivorous animal's diet consists of ripe and unripe fruit, mature and young leaves, seeds, buds and flowers. In one area of Kokrajhar District of Assam the animals have also adapted to feeding on dry rubber seeds (Medhi et al. 2004). Srivastava (2006) found in a census a total of 943 individuals of Golden Langur in 96 groups in Assam. This population had also adapted to feeding on dry rubber seeds (Medhi et al. 2004). Chakrashila Wildlife Sanctuary (CWS) is one of the 14 fragmented habitat pockets, where Golden Langurs occur in Assam and is located in the districts of Dhubri and Kokrajhar covering an area of $45.58 \mathrm{~km}^{2}$. At present 474 Golden Langurs in 66

Date of publication (online): 26 July 2011

Date of publication (print): 26 July 2011

ISSN 0974-7907 (online) | 0974-7893 (print)

Editor: Ulrike Streicher

Manuscript details:

Ms \# 02412

Received 24 February 2010

Final received 21 April 2011

Finally accepted 27 April 2011

Citation: Pathak, D.C. (2011). Organochlorine insecticide poisoning in Golden Langurs Trachypithecus geei. Journal of Threatened Taxa 3(7): 1959-1960.

Copyright: (c) D.C. Pathak 2011. Creative Commons Attribution 3.0 Unported License. JoTT allows unrestricted use of this article in any medium for non-profit purposes, reproduction and distribution by providing adequate credit to the authors and the source of publication.

Acknowledgements: The author is thankful to Dr. Prabhat Basumatary (ex veterinary officer) and Dr. Panjit Basumatary (veterinary officer) WTI, Chakrashila Wildlife Sanctuary, Assam for providing the specimen, clinical samples and necessary information, and the Head, Department of Pathology, College of Veterinary Science, Khanapara for providing necessary facilities for conducting histopathology and clinical pathology.

\section{OPEN ACCESS I FREE DOWNLOAD (C) (1) (4)}

families are present in CWS (Chetry et al. 2010).

In Kokrajhar District there

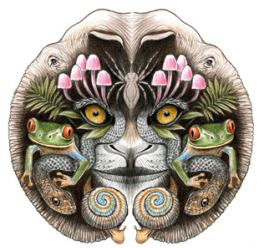
is a rubber plantation covering about 750 bighas (100ha approx.) of land bordering CWS on the north eastern side. A strip of agricultural land of about $100 \mathrm{~m}$ wide separates the CWS from the rubber plantation. Golden Langurs frequently visit the plantation area in search of food. The present report is a record of organochlorine insecticide poisoning in three Golden Langurs in CWS.

Materials and Methods: The staff of CWS spotted an adult Golden Langur in moribund condition in the forest in the early part of December 2008. It had lacerations on the head and face as if it had fallen from the tree. The animal was emaciated and unable to walk on its own. The veterinary officer of the Wildlife Trust of India (WTI) entrusted to CWS, Assam, treated the animal by dressing the wounds and injecting antibiotics, dexamethazones, DNS drip and vitamin B complex. But the animal died two days later. Blood and urine samples were collected for routine examination before the death of the animal.

Within the month two adult other Golden Langur carcasses were recovered in the same forest. All three carcasses were thoroughly necropsied. Heart blood and tissue samples were collected aseptically and sent for bacterial culture. Intestinal loops and pieces of liver and kidney in saturated salt solution were sent to the Forensic Science Laboratory, Guwahati for identification of any toxic insecticides. Representative tissue samples were preserved in $10 \%$ formol saline. Paraffin embedded tissue sections were stained with routine haematoxylin and eosin staining method for histopathology. Local WTI personnel reported that the rubber plants were regularly sprayed with some insecticides. The Golden Langurs were reported to eat the tender leaves of the plants.

Results: On postmortem examination all three animals were found to be dehydrated. No specific gross lesions were found in the visceral organs, except congestion in the liver, kidneys and intestine. The blood picture showed lower levels of haemoglobin $(7.2 \mathrm{~g} \%)$, packed cell volume $(29 \%)$ and total leucocyte count $\left(5.15 \times 10^{3} \mu \mathrm{l}^{-1}\right)$. Urinanalysis showed moderate amounts of protein and bile pigment. Histopathiologically, there was massive haemorrhage 
in the liver with necrosis of the hepatocytes, which was centrilobular to diffuse (Image 1). The kidneys showed congestion in the intertubular spaces with mild degeneration of the tubular epithelial cells. The mucosal epithelium of the small intestine was necrotic and sloughed away. The lungs showed capillary congestion and alveolar haemorrhages. In the cerebrum there was mild leptomeningitis with congestion and infiltration of mononuclear cells in the piamater. Neuronal degeneration and neuronophagia were also evident in the cerebrum. The forensic science laboratory results confirmed the case as organochlorine insecticide poisoning, as all the tissues (liver and kidney) and intestinal contents of the three animals were found positive for the insecticide.

Discussion: Organochlorine insecticide intoxication does not cause any diagnostically useful lesions. Though hepatocellular degeneration and renal tubular degeneration had been occasionally reported with certain organochlorine intoxications, such lesions were more frequently associated with prolonged exposure than acute poisoning (Peterson \& Talcott 2006). Jones et al. (1997) also described Nissl's degeneration, neuronal necrosis, centrilobular necrosis of liver and enteritis in case of oral poisoning. In the present case the lesions along with the general health of the animals suggested prolonged exposure to organochlorine insecticides by ingestion of contaminated leaves of the rubber plants over a long period of time. This was later confirmed by the findings of the forensic science laboratory. It is specifically interesting to consider that the population observed by Medhi (2004) in the same district did utilize rubber seeds as food souce without shoiwng any health problems. A comparison of organochlorine

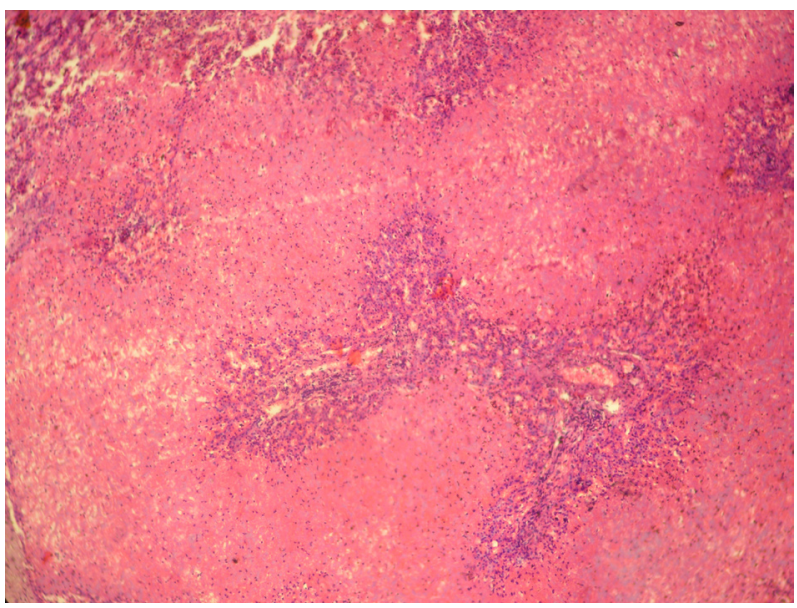

Image 1. Hepatic necrosis in a Golden Langur from Chakrashila Wildlife Sanctuary.

\section{REFERENCES}

Chetry, D., R. Chetry, K. Ghosh \& P.C. Bhattacharjee (2010). Status and Conservation of Golden Langur in Chakrashila Wildlife Sanctuary, Assam, India. Primate Conservation (25): 81-86.

Das, J., R. Medhi \& S. Molur (2008). Trachypithecus geei. In: IUCN 2011. IUCN Red List of Threatened Species. Version 2010.4. <www.iucnredlist.org>. Downloaded on 06 July 2011.

Jones, T.C., R.D. Hunt \& N.W. King (1997). Veterinary Pathology -6th Edition. Williams and Wilkins, A Wavery Publishing, Baltimore, USA, 238pp.

Medhi, R., D. Chetri, P.C. Bhattacharjee \& B.N. Patyri (2004). Status of Trachypithecus gee in a rubber plantation in western Assam; India. International Journal of Primatology 25(6): 1331-1337.

Peterson, M.E. \& P.A. Talcott (2006). Small Animal Toxicology. Second Edition. Saunders Publisher, 1232pp.

Srivastava, A. (2006). Ecology and conservation of the Golden Langur Trachypithecus geei. Primate Conservation (21): 163-170. insecticide levels in different plant parts could bring more information. 